\title{
The role of the precedent phenomenon in creating a language game in the headlines of political media discourse
}

\author{
Pogrebnyak Natalia* \\ Department of Foreign Languages, Kuban State Agrarian University, Krasnodar, Russia
}

Received 31 July 2019; Accepted 26 August 2019

\begin{abstract}
The precedent phenomenon is estimated as a productive source for creating the language game in the headlines of political media discourse. Headlines based on a language game draw the attention of the reader more quickly. There are often used precedent phenomena, understood as culturally loaded signs, known to a major part of the representatives of the same national community. That is a precedent phenomenon that may serve multiple purposes. We have focused on its effect applied in the headings. The coincidence of the background knowledge of the author and the reader contributes to the hidden influence on the images of politicians formed in the mind of the reader.
\end{abstract}

Keywords: headline • language game • precedent phenomenon • political media discourse

(C) Sciendo

\section{Introduction}

In the modern world, throughout the history of its existence, the media and political discourse have always tended to converge and intersect. It contributed to the formation of a new discursive space, located at the interface of political and media discourses. In this study, the author has represented his understanding of political media discourse as a discourse, combining the features of political and media discourse, as a set of media texts under a common political theme with the same goal - the struggle for influence and power.

The constant growth of information flow within the existing online political media discourse encourages the authors to look for new and more effective ways to attract the attention of the reader. The success of the publication often depends on its correctly chosen and sufficiently expressive heading. Historically, "the name of an article or other material in which its main content is expressed very briefly" [1] (p. 32) was determined as the title. It is the headlines that help us to navigate in various sites and articles, predicting the answers to questions about the content of the article, the author's attitude to the story being told and even the potential readers that the author is counting on. N. A. Srebryanskaya underlines the fact that the reader "labels" the entire text by the heading, thereby rejecting the work or, on the contrary, showing interest in it [2].

M. J. Zasorina describes the title as "a compressed text with a special pragmatic potential due to its suggestive and informational load" [3] (p. 25). I. N. Sokolova understands the heading of the media text as a "collection of information", which reflects the content of the text briefly and allows the addressee to predict the approximate meaning of the text before reading it [4].

When choosing the most accurate, in our opinion, definition of the headline, we will proceed from the fact that the pragmatic essence of the headline as a unit of text is its effect on the recipient. Thus, following A. Yu. Isayeva, we will consider the newspaper headline as a communicative message, and the pragmatic setting of which is the adequate transmission of the author's intention of the article to encourage the readers to read the material [5].

The term "word play" is known for centuries. There are researches concerning the difference between word play and verbal play. Delia Chiaro has investigated the term verbal play. She argues that "the term word play conjures up an array of conceits ranging from puns and spoonerisms to wisecracks and funny stories" [6]. It is unnecessary to throw a doubt upon this statement. The term "verbal play" is wider, and analysis of relevant examples is of greater interest. Russian tradition in analysing different types of discourse and functioning of playful word combinations

\footnotetext{
*Corresponding author: E-mail: natasha-kr@yandex.ru 
based on misunderstandings, changing of a word or just a context, where it is used goes back to Wittgenstein [7] as philosopher and to De Saussure [8] as linguist, who used the term Sprachspiel, in Russian it is «языковая игра» and in English it is "language game". This term "language game" was introduced by Wittgenstein in the Philosophical Studies of 1945 to describe the language as a system of conventional rules in which the speaker is involved. The concept of a language game implies pluralism of meanings. In Russian linguistics, the term came into widespread in scientific use after the publication of the work of the same name by E. A. Zemskaya, M. V. Kitaygorodskaya and N. N. Rozanova [9], although the linguistic phenomena themselves, denoted by this term, have a rather long history of the study. As indicated in this work, these are "those phenomena when the speaker 'plays' with the form of speech, when a free attitude to the form of speech receives an aesthetic task, even the most modest one. It can be a simple joke, or more or less successful sharpness, and a pun, and different types of paths (comparisons, metaphors, periphrases, etc.)". In this study, the author adheres to the term "language game" that combines philosophical and linguistic components.

Currently, questions of the study of language games in the language of the media and political media discourse, in particular, are the focus of the attention of many researchers. A language game is a deviation from the language norm, a change in the roles of a journalist and a reader, the game in the text as a stylistic device becomes the trend of development of modern media. We share the definition given by M. V. Zakharova that a language game is "a deliberate target violation of a generally accepted norm committed by a native speaker to accomplish certain tasks, i.e. we are talking about the game in the broadest sense of the term: witty talks, language jokes, parodies, intertexts, figures of speech, puns, anecdotes, game texts (as a special type of wide interaction between the author and the reader in the game text field)" [10] (p. 168).

There are various levels of language game, such as phonetic, graphic, morphological and derivational, and there is also a separate type of language play based on precedent phenomena. It is on this kind of language game - games with precedent phenomena - we will dwell in more detail.

\section{Research methods}

This study is based on a set of methods, combining both general methods of scientific research (observation, synthesis, analysis and comparison) and linguistic, i.e. semantic, contextual, stylistic and discursive analysis. In the framework of "pragmatic turn" in linguistic, we believe that the semiotic and the cultural aspects of analyses and interpretation are interrelated closely. Therefore, we apply the method of hermeneutic interpretation for the description of the characteristics of the precedent phenomena appearing in headlines of political media discourse. We have analysed 100 headlines of political media discourse, united by a common theme of creating vivid and memorable images. The hermeneutic circle is considered as understanding and mutual determination of parts through the understanding of the general context and the definition of the whole system through its parts [11, 12]. The hermeneutic circle was used as an effective method to reveal the hidden meanings of images and thereby show the cognitive aspects of the process of creativity in the image (there is an image of the political player in our research). The national and cultural specifics of the precedent phenomena were also analysed.

When studying the semiotic culture codes that are expressed through precedent texts, precedent statements, precedent situations and precedent names, we applied descriptive method, which included observation, generalization, interpretation and classification of studied units (precedent phenomena), and contextual method, which objective is to study the semantics and pragmatics of the precedent phenomena within a particular sociocultural situation. Using component analysis, we have identified the connotative meaning of studied units. The emphasis in this analysis is on political contexts for the production and interpretation of language games based on precedent phenomena.

\section{Precedent phenomena: a theoretical review}

There are combinations of words or whole expressions referring to different historical events or political figures or well-known books and films. In Russian linguistics, these specific language units are called precedent phenomena. Precedent phenomena have been investigated by many Russian linguists since the term "precedent text" was introduced by Yuri Karaulov in the 1980s. He defined it as a special text (1) significant for a particular person in cognitive and emotional relationships, (2) having a superpersonal character, i.e. well-known and wide-ranging 
given personality, including its predecessors and contemporaries and (3) such the appeal to which is constant in the discourse of a given linguistic personality [13]. According to Yu. N. Karaulov, precedent texts have such basic distinguishing features as common knowledge and reinterpretation (1986). In this regard, it is necessary to emphasize the importance of knowledge of native speakers about precedent texts, since "knowledge of precedent texts is an indicator of belonging to a given epoch and its culture, whereas ignorance, on the contrary, is a prerequisite of rejection from the corresponding culture" [13] (p. 105).

However, not only texts can have a precedent character. According to the theory of precedence, a large contribution to the development of which was made by D. B. Gudkov, V. V. Krasnykh, I. V. Zakharenko and D. V. Bagaev, there are some linguistic phenomena with a precedent character. According to D. B. Gudkov, V. V. Krasnykh, I. V. Zakharenko and D. V. Bagaev, the precedent phenomena include a precedent text, a precedent situation, a precedent statement and a precedent name. The scientists believe that the precedent text and the precedent situation are broader concepts, and they often cannot be used in speech in its entirety. In this regard, they introduce into circulation such a concept as a symbol of a precedent text or a precedent situation, which can be used as a precedent name and a precedent statement [14].

Precedent phenomena take a definite place in the structure of a linguistic personality. They are realized in its discourse and are reflected in the features of not only the individual but also the collective pictures of the world. In this connection, the thesis that events and facts reflecting the life of a certain linguistic person, as well as a certain linguocultural community, can be a source of precedent phenomena seems to be legitimate [15].

The precedent phenomena are understood as culturally loaded signs, known to a significant part of the representatives of the national-cultural community [16]. Zolotarev [17] defines precedent phenomena as "culturally specific language units, functioning in a text". The use of precedent texts is based, most often, on the transformation of the component composition of "old" known phrases and expressions, which undoubtedly enhances their expressive capabilities [18].

This definition determines precedent phenomena according to modern tendencies in linguocultural studies as "discourse units that are regularly renewed in speech, known to all members of the national-linguistic and cultural community, and have a common minimized connotatively colored perception invariant, the appeal to which is understandable without additional decoding" ([19], p. 52).

One of the main criteria for the selection of cases referring to precedent phenomena is their comprehensibility and general knowledge. The precedent phenomena should be easily recognizable and decoded by the addressees even during complex transformations.

\section{Precedent phenomena: current analysis}

The objective of this study is to determine the role of the precedent phenomenon in creating a language game in the headlines of political media discourse.

In the course of the study, examples of a language game found in the headings of political media discourse, and particular examples of a language game, based on an appeal to precedent phenomena, were identified and analysed. This study was based on the articles published by the German media in 2018-2019.

The precedent phenomena include poetic and prosaic quotations from literary works, the names of literary and musical works, phrases from movies and songs, slogans of advertising, jokes and biblical expressions, names of literary heroes, historical personalities and political figures. Various precedent phenomena may change; some precedent texts or names are forgotten and are not precedent any more, and other texts, on the contrary, become precedent for a long time.

Currently, precedence as a linguistic-cultural phenomenon is closely related to the media. Precedent phenomena (texts, statements, names and situations) often become the object of a language game. They can be presented in the unchanged form and the transformed form.

The common ways to transform precedent phenomena are as follows: adding components, cutting components and changing components.

For example, the title "Angsthasen auf der Regierungsbank" in the Internet version of the German magazine Stern has an allusion to Aesop's fable about the lion and the cowardly bunny. And this is not about bunnies, but about representatives of the German parties CDU, CSU and SPD, as well as their indecision in making decisions on some issues. The headline is attractive and intriguing enough to make you want to read the article and find out who these little cowards in the headline are and what they are afraid of. 
The heading "Geliebter Nazi" (presented on a big Internet news portal welt.de) arouses the interest of the reader and even confuses because the article is not at all of a political nature, it is not about the policies of the times of fascist Germany, the beloved Nazi is about the Chemnitzer FC football club. The adding component "geliebter" is one of the examples of precedent phenomena transformations.

The heading "Nemo zieht in den Krieg", appeared on welt.de (online news portal welt.de), is an allusion of two heroes at once: Captain Nemo from Jules Verne's novels and fish Nemo from the movie "Finding Nemo", the analogy with which is drawn to emphasize how small the role of the participant in the hostilities in eastern Ukraine is.

The headline "Von der Leyen und der 'Tatortreiniger'" (online news portal welt.de) draws an analogy from the TV show Cleaner on Norddeutscher Rundfunk, where the main character cleans up at the crime scene: blood, the remains of the victim, etc. There is the name of the minister of Defence (Ursula von der Leyen) and TV show Cleaner in the same row. What is the purpose of the author of the article? Our attention. And he has got it, using the method of adding components to the precedent name again.

The title "Scholz kann nicht alle Wünsche erfüllen", presented in the Internet version of the popular German newspaper Sueddeutsche, is an allusion to Santa Claus. Even the fabulous Grandfather Frost can, unfortunately, not all wishes come true: "der Weihnachtsmann will ja jedem Kind was schenken und daher kann nicht jedem ALLE Wünsche erfüllen". The ironic headline reminds us that if Santa Claus is not omnipotent, then, of course, Finance Minister Olaf Scholz - too.

The title "Ein Riese ist besser als zwei Zwerge", appeared also in the Internet version of the German newspaper Sueddeutsche, mentions fairy-tale heroes: the giant and the dwarfs. This title is sure to attract the attention of readers; it is necessary to find out who we are talking about. The article criticizes the possible amalgamation of Deutscher Bank and Commerzbank. And already in the title, the reader feels this criticism and negative attitude of the author to the events described.

The headline "Der 'Bloody Sunday' schmerzt noch immer" (in the Internet version of the German newspaper Sueddeutsche) is an allusion to the idiom about a wound that still hurts: Die Wunde schmerzt noch immer. Here, there is a replacement of concepts, instead of a specific wound and physical pain, Bloody Sunday of 30.01 .1972 is mentioned. On this day, the protest march in Northern Ireland turned into a massacre with thirteen dead. The memory of this day now is a heartache, a sense of injustice that has not been drowned out for the past years.

\section{Conclusion}

Since a language game is often used to form a certain (often negative) attitude to a particular political event or figure, this indicates its influencing and estimating potential. In this case, the evaluation is formed not so much due to the lexical meaning of the units, but rather due to the associations and connotations that the allusion to a particular work causes.

The analyzed material shows that the precedent phenomenon is a productive source for creating the effect of a language game in the headlines of political media discourse. This kind of language game necessarily requires background knowledge from the reader that would coincide with the author's background knowledge: to decipher adequately and enjoy the game. That is why our compilation is dominated by examples of the language game in the headlines, where well-known literary works appear as sources of precedent phenomena, as they are most easily interpretable. The allusion to the line from the song is undoubtedly a delicate way, but most likely not very understandable. But the allusion to the fabulous heroes, Santa Claus is a hint understandable to everyone.

We have not found any examples of precedent phenomena functioning in the headings as verbatim reproduction (word-for-word citation). All the cases studied and analyzed are the examples of transformed precedent names, statements. It serves to the creation of new meanings, completing already-known popular images and situations with new characteristics and new vision affected by the attitude of the author. Therefore, the headings become more expressive, the author's point of view is expressed explicitly or implicitly.

Thus, precedent phenomena allow one to estimate not only what the author thinks about any real person or a situation but also it gives an understanding of the direction, which the impact is in and what is the value system in a given society. The headings based on the language game are distinguished by their originality and expressiveness, which will surely attract the reader's attention to the article and will contribute to the hidden impact on the images of politicians formed in the mind of the reader. 


\section{References}

[1] Kulakov, A. N., 1982. The headline and its design in the newspaper. Leningrad: Leningrad Publishing House. University, p. 32.

[2] Srebryanskaya, N. A., 2005. Deixis and its projections in the literary text: A monograph. Voronezh: VSPU, p. 76.

[3] Zasorina, M. E., 2009. Pragma-Intertextual Characteristics of the Headline Discourse of the Media (on the Example of the Magazines "Kommersant Power" and "The Economist"). PhD thesis, Tobolsk, p. 25.

[4] Sokolova, I. N., 2006. The Variability of the Perception of Media Texts as the Representation of the Diversity of Relations in the Communicative System "Man-Society" (Experimental Study). PhD thesis, Ulyanovsk, p. 61.

[5] Isaeva, A. Yu., 2017. Communicative and Pragmatic Features of a Newspaper Headline (on the Material of English Internet Publications). PhD thesis, Tula, pp. 30-31.

[6] Delia, C., 1992. The Language of Jokes: Analyzing Verbal Play. Journal of Women's Health.

[7] Wittgenstein, L., 2013. Tractatus Iogicophilosophicus. London: Routledge.

[8] De Saussure, F., 2011. Course in general linguistics. New York: Columbia University Press.

[9] Zemskaya, E. A., Kitaigorodskaya, M. A., Rozanova, N. N., 1983. Language game. Russian colloquial speech. Moscow.

[10] Zakharova, M. V., 2006. Language game as a fact of the modern stage of development of the Russian literary language. Znamya, May, № 5, pp. 159-168.

[11] Sukhoverkhov, A. V., 2013. Ecological approach to the study of language, communication and cognition. Bulletin of Tomsk State University. Journal of Philosophy. Sociology and Political Science, 4(24), 48-54.

[12] Sukhoverkhov, A. V., 2014. Sovremennyye tendentsii $\vee$ razvitii ekolingvistiki. YAzyk $i$ kul'tura, 3(27), 166-175.

[13] Karaulov, Yu. N., 1986. Russian language and linguistic personality. Moscow: Science, p. 105.

[14] Zakharenko, I., Krasnykh, V., Gudkov, D., et al., 1997. Precedent name and precedent statement as symbols of precedent phenomena. Language, Consciousness, Communication, p. 82.

[15] Nazarova, R. Z., Zolotarev, M. V., 2015. Precedent phenomena: problems of definition and classification of precedent phenomena. News of Saratov University. New Series. Philology Series. Journalism, 15(2), 17-23.

[16] Gasparov, B. M., 1996. Language, memory, image. Linguistics of language existence. Moscow: New Literary Review, p. 69.

[17]. Zolotarev, M., 2013. Precedent Phenomena: The Role of Cultural Reference in Dostoevsky's Novel Demons. Doctoral dissertation, University of Missouri, Columbia.

[18] Chernogrudova, E. P., 2003. Headlines with Precedent Texts in Contemporary Journalism (on the Materials of the Central, Regional and Local Press). PhD thesis, Voronezh, p. 22.

[19] Smykunova, N., 2003. Precedent Phenomena in Communication of Russian Linguistic Personality and the Process of Teaching Russian as a Foreign Language. PhD thesis, Moscow, p. 52. 